\title{
MENINGKATKAN KEMANDIRIAN BELAJAR MAHASISWA PENDIDIKAN MATEMATIKA DI MASA PANDEMI COVID-19 MELALUI PEMBELAJARAN BLENDED LEARNING
}

\author{
Rasid Ode $^{{ }^{*}}$, Kasriana ${ }^{1}$, Safarin Zurimi ${ }^{1}$ \\ IUniversitas Darussalam Ambon \\ *Email: rasidode@unidar.ac.id
}

\begin{abstract}
This research was conducted at Darussalam University Ambon with the research subjects being students of mathematics education in the third semester of the academic year 2021/2022. This study aims to determine student responses to learning independence through blended learning using several indicators of learning independence. The results showed that most (80\%) students in the third semester of the Mathematics Education Study Program at the University of Darussalam Ambon were in the good category with the following description: : (1) $69 \%$ of students have learning initiatives; (2) diagnose the learning needs of $76 \%$ of students; (3) setting the target or learning objectives owned by students as much as $73 \%$; (4) monitor, regulate and control $81 \%$ owned by students; (5) views difficulties as challenges that are owned by $73 \%$ of students; (6) utilize and look for relevant sources owned by students as much as $75 \%$; (7) choose and apply learning strategies owned by students as much as 77\% ; (8) evaluate the process and learning outcomes owned by students as much as 75\%; (9) students' self-efficacy (self-concept) is $78 \%$.
\end{abstract}

Keywords: independent learning, covid-19 pandemic, blended learning

\section{PENDAHULUAN}

Matematika merupakan salah satu mata pelajaran yang diajarkan mulai dari sekolah dasar, sekolah menengah, hingga perguruan tinggi. Hal ini seringkali tidak menjadi hiasan, karena dengan menguasai dan memahami aritmatika dipercaya individu-individu Indonesia dapat menguasai dan tertarik untuk menciptakan inovasi. Untuk mengarahkan peserta didik agar mampu mengungkap permasalahan ilmiah, seorang pendidik harus mampu merencanakan model pembelajaran. Sebuah cara belajar bisa cocok untuk satu siswa, tetapi mungkin tidak cocok untuk siswa lain. Biasanya karena kenyataan bahwa setiap 
siswa bisa menjadi orang yang istimewa dan memiliki karakteristik yang berbeda (Kasriana, rasid ode, 2019)

Terkait dengan kedudukan pendidik selaku agen pendidikan, guru dituntut bisa membagikan pembelajaran secara maksimal dengan memakai bermacam tata cara serta model pembelajaran yang disesuaikan dengan ciri siswa.( Wina Sanjaya, 2006) menegaskan kalau seseorang pendidik butuh mempunyai keahlian merancang serta mengimplementasikan bermacam strategi pembelajaran yang dikira sesuai dengan atensi serta bakat dan cocok dengan taraf pertumbuhan peserta didik, tercantum didalamnya menggunakan bermacam sumber serta media pendidikan buat menjamin daya guna pembelajaran. Salah satu model pendidikan merupakan blended learning. (Yendrik, 2011) mengartikan blended learning selaku perpaduan tata muka serta online learning buat menolong pengalaman kelas untuk meningkatkan teknologi serta komunikasi. Blended Learning merupakan campuran belajar tatap muka, offline, serta online (Dwiyogo, 2018). Blended learning merupakan suatu model pendidikan yang mencampurkan antara pendidikan tatap muka (faceto- face) dengan e- learning. Blended learning ialah konsep baru dalam pendidikan dimana penyampaian materi bisa dicoba di kelas serta online (Bielawski danMetcalf dalam Husamah, 2014). Sedangkan (Chaeruman, 2011) menarangkan blended learning selaku pembelajaran yang mengombinasikan setting pendidikan synchronous serta asynchronous secara pas guna buat menggapai Tujuan pembelajaran. Berdasarkan definisi diatas, membagikan cerminan kalau blended learning ialah campuran antara pendidikan tatap muka serta pendidikan online dengan dorongan teknologi data serta komunikasi secara pas guna buat menggapai tujuan pendidikan, paling utama pada waktu pandemic covid- 19.

Blended Learning sangat sesuai digunakan di dunia pembelajaran pada suasana pandemic semacam dikala ini. Wabah corona virus disease 2019 (Covid19) yang sudah menyerang 215 negeri didunia, memberikan tantangan tertentu untuk lembaga pendidikan, spesialnya Perguruan Besar. Buat melawan Covid- 19 Pemerintah sudah melarang buat berkerumun, pembatasan social (social distancing) serta melindungi jarak raga (physical distancing), mengenakan masker serta senantiasa mencuci tangan. Lewat Departemen Pembelajaran serta Kebudayaan Pemerintah sudah melarang perguruan besar buat melakukan perkuliahan tatap muka (konvensional) serta memerintahkan buat menyelenggarakan perkuliahan ataupun pendidikan secara daring (Pesan Edaran Kemendikbud Dikti Nomor. 1 tahun, 2020). Akademi tinggi dituntun buat bisa menyelenggarakan pendidikan secara daring ataupun online.

Statment ini sama dengan penemuan riset (Sari, 2013) yang merumuskan kalua model blended learning sukses tingkatkan kemandirian belajar sebanyak 72 , 80\%. Tidak hanya itu berdasarkan hasil penelitian (Sutisna, 2016) pula merumuskan kalau model pendidikan blended learning efisien buat tingkatkan 
kemandirian belajar partisipan didik. Kemandirian umumnya diisyarati dengan keahlian memastikan kreatif, serta inisiatif, mengendalikan tingkah laku, bertanggung jawab, sanggup menahan diri, membuat keputusan- keputusan sendiri, dan sanggup menanggulangi permasalahan tanpa terdapat bantuan dari orang lain (Desmita, 2012). Kemandirian belajar (Self Regulated Learning) diperlukan oleh peserta didik dalam membangun konsep serta prinsip untuk dipelajarinya. Kemandirian belajar ialah sesuatu pemahaman diri buat belajar dengan tidak tergantung kepada orang lain serta merasa bertanggung jawab dalam menggapai tujuan yang di idamkan (Hamka, D, Vilmala, B. K., 2019). Kemandirian belajar merupakan suatu faktor berarti dalam sesuatu pendidikan. (Ranti, Meter, 2017).

Bersumber pada hasil pemaparan di atas, hingga riset ini bertujuan buat mengenali sejauh mana keahlian mahasiswa dalam meningkatkan kemandirian belajar di masa pandemic Covid- 19 dengan menggunakan model Blended Learning. Kemandirian belajar yang dimaksud dalam perihal ini berbentuk inisiatif belajar, mendiagnosa kebutuhan belajar, menetapkan tujuan pendidikan, menggunakan serta Mencari Sumber Yang Relevan, memilah serta mempraktikkan Strategi Belajar, mengevaluasi Proses serta Hasil Belajar, dan tingkatkan keyakinan diri.

\section{METODE PENELITIAN}

Penelitian ini menggunakan metode deskriptif kualitatif karena data diperoleh dari sumbernya, terutama siswa menggunakan metode yang lebih natural, yaitu dengan mengamati secara langsung dan menyebarkan angket sehingga mereka dapat menarik kesimpulan dari isi yang diteliti. Penelitian ini bertujuan untuk mengetahui respon mahasiswa Pendidikan matematikan universitas Darussalam Ambon terhadap kemandirian belajar melalui blended learning

Penelitian ini di laksanakan di Universitas Darussalam Ambon khususnya program studi pendidikan matematika Fakultas Keguruan dan Ilmu Pendidikan. Pelaksanaan penelitian pada tahun ajaran 2021/2022 Sampel dalam penelitian ini penulis mengambil $100 \%$ jumlah populasi yaitu mahasiswa semester III program studi pendidikan matematika Universitas Darussalam Ambon.

Data penelitian yang diperoleh dari hasil survey kuesioner kemudian diolah sesuai dengan teknologi pengolahan yang telah ditentukan sebelumnya. Pengolahan data dalam penelitian ini dilakukan dengan langkah-langkah sebagai berikut:

a. Menentukan kuesioner yang telah diolah yaitu kuesioner yang memenuhi kriteria yang ditentukan dalam review kuesioner. 
b. Menentukan alternatif kondisi jawaban untuk setiap item dalam angket, yaitu jawaban sangat setuju dengan syarat dan berbobot 4 , setuju dengan bobot 3 , tidak setuju dengan bobot 2 , dan sangat tidak setuju dengan bobot 1 .

c. Memproses kuesioner.

d. Menetapkan tolak ukur untuk kategori hasil perhitungan persentase sebagai pedoman untuk menginterpretasikan data yang diperoleh dari perhitungan persentase.

\section{HASIL DAN PEMBAHASAN}

\section{Hasil Penelitian}

Peneliti menyebarkan 20 kuesioner kepada responden dan memperoleh data kemandirian belajar siswa melalui blended learning selama masa pandemi Covid-19. Berdasarkan hasil survei angket kemampuan belajar mandiri mahasiswa diklasifikasikan menurut standar yang telah ditentukan, dan diperoleh data tingkat kemampuan belajar mandiri mahasiswa pada semester III Universitas Ambon Darussalam. Tabel berikut mengklasifikasikan kemampuan belajar mandiri.

Tabel 1. Kategorisasi Tingkat Self Regulated Learning setelah Pembelajaran Blended Learning pada Mahasiswa Semester III Program Studi Pendidikan Matematika Universitas Darussalam Ambon

\begin{tabular}{|c|c|c|c|}
\hline Rentang Skor & Kategori & Frekuensi & Prensentase \\
\hline $46-73$ & Tidak Baik & - & $0 \%$ \\
\hline $74-101$ & Kurang Baik & - & $0 \%$ \\
\hline $102-129$ & Cukup & 2 & $10 \%$ \\
\hline $130-157$ & Baik & 16 & $80 \%$ \\
\hline $158-184$ & Sangat Baik & 2 & $10 \%$ \\
\hline \multicolumn{2}{r|}{ Total } & 20 & $100 \%$ \\
\hline
\end{tabular}

Dari penyajian data di atas menunjukkan bahwa dari keseluruhan mahasiswa Pendidikan matematika Universitas Darussalam Ambon yang di teliti:

1. $0(0 \%)$ mahasiswa yang memiliki tingkat self regulated learning yang Tidak Baik.

2. $0(0 \%)$ mahasiswa yang memiliki tingkat self regulated learning yang Kurang baik.

3. $2(10 \%)$ mahasiswa memiliki tingkat self regulated learning yang cukup.

4. $\quad 16(80 \%)$ mahasiswa memiliki tingkat self regulated learning yang baik.

5. $2(10 \%)$ mahasiswa memiliki tingkat self regulated learning yang sangat baik

Dalam diagram batang, pembagian dan sebaran subjek berdasarkan tingkat 
selfregulated learning -nya tergambar sebagai berikut:

\section{Frekuensi}

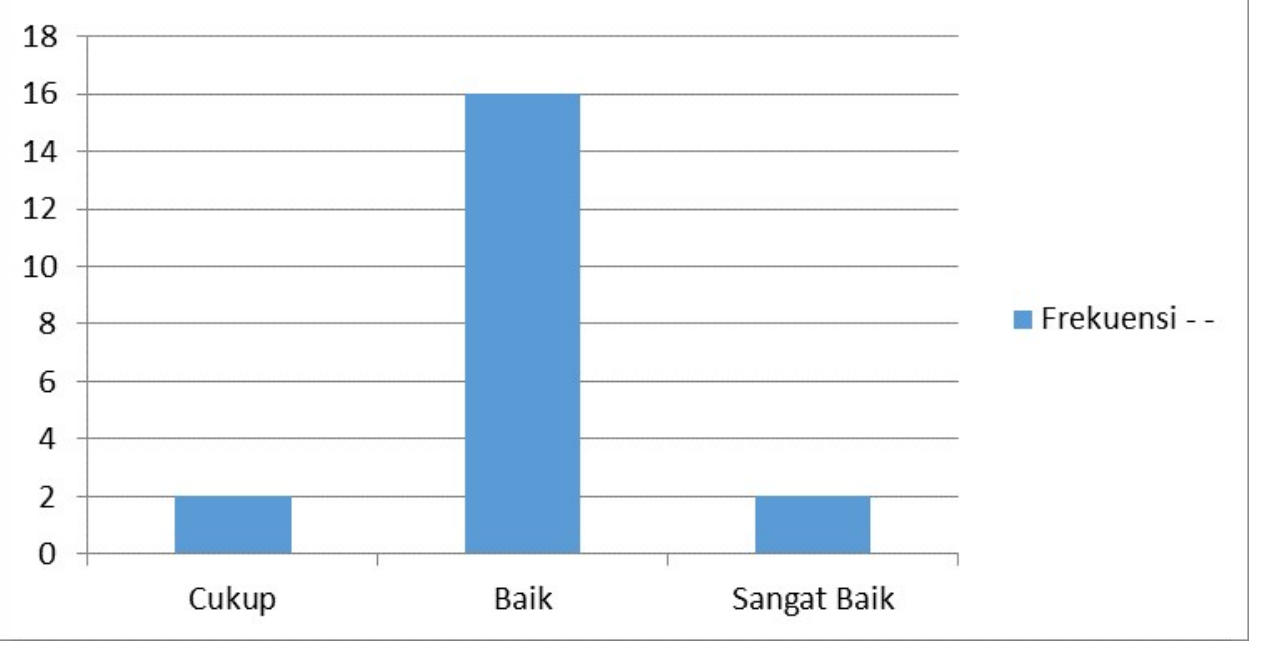

Gambar 1. Diagram batang, komposisi dan sebaran subjek berdasarkan tingkat selfregulated learning

Berdasarkan diagram batang di atas, peneliti menyimpulkan bahwa sebagian besar $(80 \%)$ mahasiswa semester III program studi pendidikan matematika universitas darussalam ambon berada pada kategori baik.

Berikut penggolongan butir-butir indikator Self-Regulated Learning berdasarkan hasil penelitian.

Table 2. Penggolongan Butir-Butir Indikator Self-Regulated Learning

\begin{tabular}{|l|l|c|c|}
\hline \multirow{2}{*}{ No } & \multicolumn{1}{|c|}{ Indikator } & Butir & Persentase \\
\hline \multirow{2}{*}{1} & Inisiatif Belajar & 5 & $79 \%$ \\
\cline { 3 - 4 } & & 1 & $75 \%$ \\
\cline { 3 - 4 } & & 6 & $46 \%$ \\
\cline { 3 - 4 } & & 20 & $76 \%$ \\
\cline { 3 - 4 } & & 30 & $69 \%$ \\
\cline { 3 - 4 } 2 & Mendiagnosa Kebutuhan Belajar & 39 & $71 \%$ \\
\cline { 3 - 4 } & & 1 & $78 \%$ \\
\cline { 3 - 4 } & & 22 & $79 \%$ \\
\cline { 3 - 4 } & & 26 & $70 \%$ \\
\hline 3 & Menetapkan Target Atau Tujuan & 4 & $\mathbf{8 1} \%$ \\
\cline { 3 - 4 } & Belajar & 12 & $66 \%$ \\
\hline
\end{tabular}




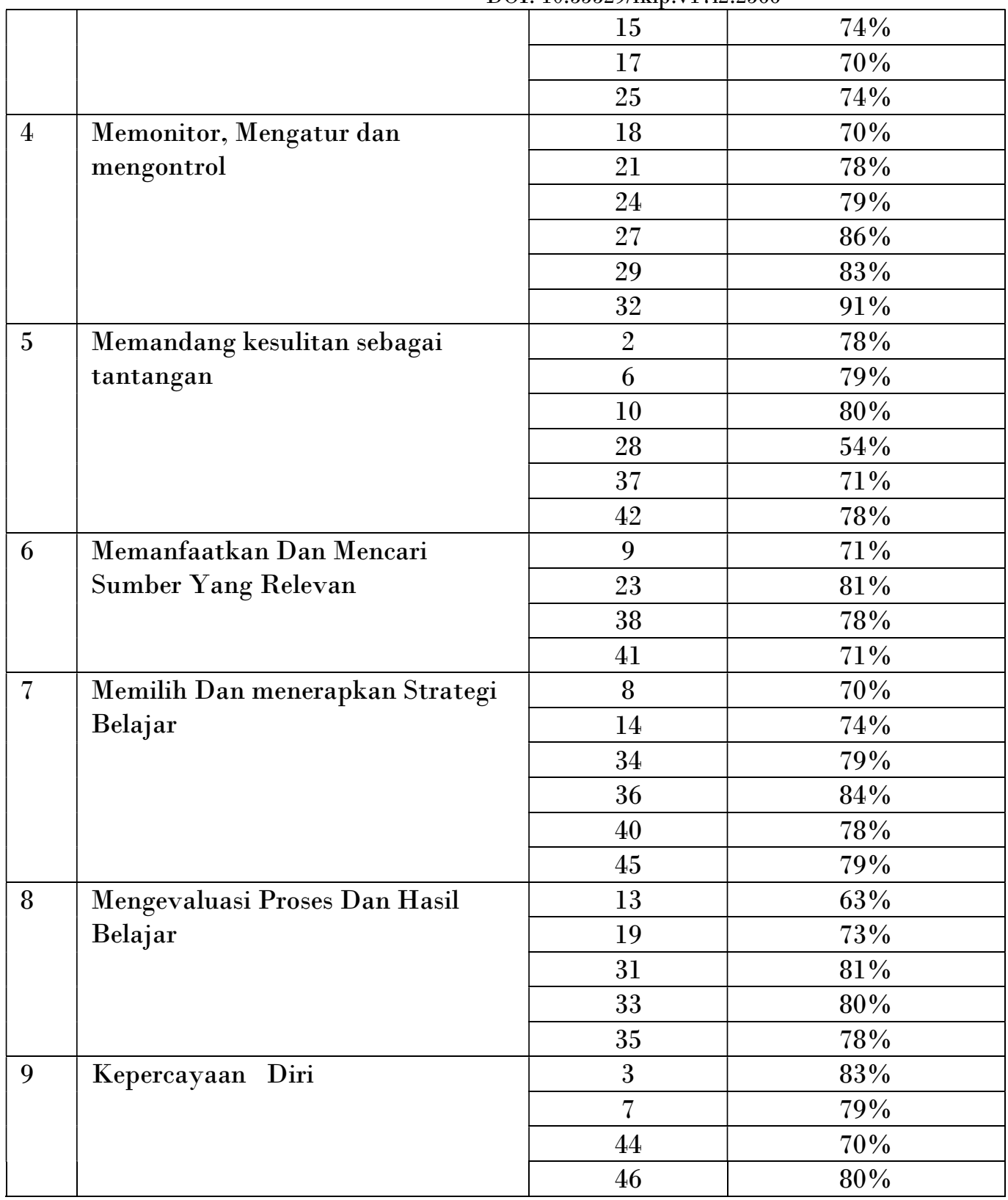

Berdasarkan data pada tabel di atas menunjukkan bahwa kemampuan mahasiswa untuk setiap Butir pada indikator penilaian self regulated learning berada di atas 50 persen dari 20 mahasiswa yang telah mengisi angket, namun pada butir 16 kemampuan mahasiswa dalam self regulated learning hanya pada tingkat $46 \%$. 


\section{PEMBAHASAN}

Berdasarkan data hasil penelitian dan observasi, tampak perilaku mahasiswa semester III program studi pendidikan matematika memiliki self regulated learning yang Baik. Hasil tersebut dilihat dari presentase mahasiswa yang berada dalam kategori Baik (80\%) lebih banyak dibandingkan mahasiswa yang berada dalam kategori Cukup (10\%), Kurang baik (0\%) maupun tidak baik $(0 \%)$. Hal ini berarti bahwa sebagian mahasiswa memiliki orientasi tujuan dalam belajar, sehingga mahasiswa dapat meregulasi dirinya sendiri dalam belajar dengan baik.

Hasil penelitian ini sejalan dengan hasil penelitian yang dilakukan oleh Ganjar Susilo dengan hasil penelitiannya adalah melalui blended learning mata kuliah kalkulus lanjutan, dapat diperoleh tanggapan dan pendapat mahasiswa terkait pembelajaran mandiri. Jenis penelitian yang dilakukan adalah penelitian deskriptif kualitatif. Hasil survei yang diperoleh adalah pada mata kuliah kalkulus lanjutan persentase respon yang belajar mandiri melalui blended learning adalah $64 \%$. Hasil ini menunjukkan bahwa mahasiswa dengan kemandirian belajar yang baik menggunakan sumber belajar secara kreatif dan aktif dalam blended learning, dapat membuat keputusan sendiri tentang tanggung jawab dan tanggung jawabnya sebagai mahasiswa, dan mahasiswa dapat menilai nilai akhir (baik atau sangat baik) menggabungkan strategi pembelajaran setiap mahasiswa dan adanya blended learning, sehingga mahasiswa dapat menyelesaikan pekerjaan rumahnya tepat waktu dan mengikuti pembelajaran sesuai dengan bimbingan dosen.

Peneliti lain juga telah melakukan penelitian yang hampir serupa yang dilakukan oleh siska dan kawan-kawan dengan Tujuan buat melihat pengaruh model blended learning selaku sesuatu inovasi pendidikan sepanjang covid- 19 dilihat dari kemandirian belajar oleh mahasiswa. Desain penelitiannya merupakan pre experimental design wujud One Group Pretest- Postest dengan metode penentuan ilustrasi secara random sampling. Instrumen riset yang digunakan merupakan angket. Informasi dianalisis memakai metode analisis informasi kuantitatif dengan menggunakan uji statistik yaitu inferensial parametrik. Uji hipotesis memakai uji t. Berdasarkan hasil perhitungan dengan statistik uji t maka diperoleh nilai $\mathrm{t}=3,41, \mathrm{t}$ tabel $=2$, 093. Jadi hipotesis $\mathrm{H} 1$ diterima yang maksudnya terdapat pengaruh model Blended Learning pada kemandirian belajar. Blended learning pengaruhi motivasi, ketertiban serta tanggung jawab mahasiswa untuk lebih giat belajar. Blended learning pula pengaruhi inisiatif mahasiswa untuk belajar serta kemauan mengevaluasi sendiri tingkat keberhasilannya dalam pendidikan

Berikut kemampuan self regulated learning berdasarkan indikator pencapaian kemandirian setelah pembelajaran blended learning: 
a. Inisiatif Belajar

Berdasarkan penelitian diperoleh $79 \%$ mahasiswa berusaha keras mempelajari materi pelajaran, $75 \%$ bekerja sama dengan teman tentang pelajaran, $46 \%$ siswa mampu mengulang materi pelajaran dalam waktu yang lama, $76 \%$ mampu mengulan materi, $69 \%$ berinisiatif mengulang pelajaran di rumah.

b. Mendiagnosa kebutuhan belajar

Berdasarkan penelitian diperoleh 79\% mahasiswa mampu merencanakan jadwal sesuai proritas, $70 \%$ mampu mengatur jadwal berdasarkan keperluan, dan $78 \%$ mampu mengatur jadwal dengan fleksibel

c. Menetapkan Tujuan

Belajar Berdasarkan hasil penelitian diperoleh 81\% mahasiswa memahami manfaat dan tujuan belajar, 66\% mempunyai target yang ingin dicapai dalam belajar, serta $74 \%$ mempunyai rencana kedepan setelah proses pembelajaran selesai.

d. Memonitor, Mengatur dan mengontrol

Berdasarkan hasil penelitian diperoleh 70\% mampu mengatur jadwal belajar diluar jam pelajaran, 78\% mampu menyelesaikan tugas dengan tepat waktu, $78 \%$ mengerjakan tugas secara mandiri, $86 \%$ tekun dalam belajar, dan $91 \%$ siap belajar setiap waktu.

e. Memandang kesulitan terhadap tantangan

Berdasarkan hasil penelitian diperoleh $78 \%$ mencoba memahami kegagalan. 79\% mampu melawan ketakutan dalam proses pembelajaran, 80\% mampu menyelesaikan masalah dalam proses pembelajaran, dan $71 \%$ teliti dalam mengerjakan tugas

f. Memanfaatkan Dan Mencari Sumber Yang Relevan

Berdasarkan hasil penelitian diperoleh $81 \%$ mahasiswa memanfaatkan internet sebagai sumber belajar, 78\% mencari literasi tambahan jika mengalami kesulitan belajar, dan $71 \%$ menunjungi perpustakaan untuk mengerjakan tugas.

g. Memilih Dan menerapkan Strategi Belajar

Berdasarkan hasil penelitian diperoleh $74 \%$ memiliki trik khusus dalam belajar, 79\% mampu merumuskan strategi belajar yang tepat, 84\% meringkas materi ajar, dan $79 \%$ mahasiswa mencatat setiap materi yang di terima

h. Mengevaluasi Proses Dan Hasil Belajar

Berdasarkan hasil penelitian diperoleh $63 \%$ mahasiswa mengoreksi tugas sebelum diperiksa dosen, $73 \%$ menuangkan semua pengetahuan yang telah diperoleh ketika mengerjkana tugas, $81 \%$ memastikan jawaban berkali-kali sebelum tugas dikumpulkan, dan $\mathbf{7 8 \%}$ bekerja mandiri dalam menyelesaikan ulangan. 
i. Kepercayaan Diri

Berdasarkan hasil penelitian diperoleh 83\% berani tampil di depan kelas, $79 \%$ memahami materi yang disajikan, $70 \%$ yakin mampu mengerjakan tugas yang diberikan secara mandiri, dan $80 \%$ yakin mendapatkan nilai yang bagus ketika ulangan

Berdasarkan persentase dari indikator kemandirian belajar dikatakan dalam kategori baik, namun ada beberapa indikator yang harus menjadi perhatian tenaga pendidik seperti pada beberapa poin yang sangat rendah seperti peserta didik kurang dalam mengulang materi di rumah, kurang mampu dalam mengatur jadwal pembelajaran dan juga kurang dalam hal pengerjaan tugas. Hal ini harus diperhatikan oleh tenaga pendidik dalam mengelolah kelas baik dengan menggunakan metode blended learning maupun metode lain agar menunjang kemampuan dan atau pengetahuan anak didik yang kemudian akan meningkatkan kualitas pembelajaran. Asumsi ini diperkuat oleh adanya bukti dalam penelitian bahwa terdapat hubungan yang sangat kuat antara profesionalisme guru baik dengan penguasaan materi pembelajaran maupun dengan penguasaan metode dan evaluasi belajar.

\section{SIMPULAN}

Berdasarkan Hasil penelitian menunjukkan bahwa sebagian besar (80\%) mahasiswa semester III program studi pendidikan matematika Universitas Darussalam Ambon berada pada kategori baik dengan penjabaran sebagai berikut: (1) inisiatif belajar dimiliki mahasiswa sebanyak $69 \%$; (2) mendiagnosa kebutuhan belajar dimiliki oleh mahasiswa sebanyak 76\% ; (3) menetapkan target atau tujuan belajar dimiliki oleh mahasiswa sebanyak $73 \%$; (4) memonitor, mengatur dan mengontrol dimiliki oleh mahasiswa sebanyak $81 \%$; (5) memandang kesulitan sebagai tantangan dimiliki oleh mahasiswa sebanyak 73\%; (6) memanfaatkan dan mencari sumber yang relevan dimiliki oleh mahasiswa sebanyak 75\%; (7) memilih danmenerapkan strategi belajar dimiliki oleh mahasiswa sebanyak $77 \%$; (8) mengevaluasi proses dan hasil belajar dimiliki oleh mahasiswa sebanyak 75\%; (9) selfefficacy(konsep diri) dimiliki oleh mahasiswa sebanyak $78 \%$.

\section{SARAN}

Berdasarkan hasil penelitian, maka dapat diberikan beberapa saran sebagai berikut

1. Bagi para pendidik untuk selalu memberikan motivasi kepada peserta didik dalam situasi apapun sehingga kemandirian belajar peserta didik terwujud dengan baik dan semakin meningkat 
2. Bagi peserta didik agar mampu menumbuhkan sikap (1) inisiatif belajar; (2) mendiagnosa kebutuhan belajar; (3) menetapkan target atau tujuan belajar; (4) memonitor, mengatur dan mengontrol; (5)memandang kesulitan sebagai tantangan; (6) memanfaatkan dan mencari sumber yang relevan; (7) memilih danmenerapkan strategi belajar; (8) mengevaluasi proses dan hasil belajar; (9) selfefficacy (konsep diri).

\section{DAFTAR PUSTAKA}

Chaeruman, U.A. 2011. Implementing Blended Learning: A Case Based Sharing Experience. Diakses dari http://www.teknologipendidikan.net/2011/06/21/impementing-blendedlearning-a-case-based-sharing-experience/.

Desmita. 2012. Psikologi Perkembangan Peserta Didik. Bandung. PT Rineka Rosdakarya

Dwiyogo,W.D.(2018). Pembelajaran Berbasis Blended Learning. Depok: Rajawali Pers.

Fiman, F., \& Rahayu, S. (2020). Pembelajaran Online di Tengah Pandemi Covid-19. Indonesian Journal of Educational Science(IJES). 2(2), 81-89.

Hamka,D.\&Vilmala,B.K.(2019). Pengembangan Perangkat Pembelajaran Blended Learning Melalui Aplikasi Google Classroom Untuk Peningkatan Kemandirian BelajarMahasiswa. Journal of Education Informatic Technology and Science (JeITS), 1(2), 145-154.

kasriana, \& R.Ode. 2019. DESCRPTION Of Trigonometry Problem Solving Abilities

BasenOnPersonality TypeAndMathematicsLearningAnxietyLevelsOfTheStu dentAtSman6 Makassar.DAYA MATEMATIS : Jurnal Inovasi Pendidikan Matematika, Volume 7No. 1

Nana Sudjana.2010. Dasar-Dasar Proses Belajar Mengajar. Bandung. Sinar Baru Algensindo

Ranti,M.G,et.al. (2017). Pengaruh Kemandirian Belajar (Self Regulated Learning) terhadap Hasil Belajar Mahasiswa pada Mata Kuliah Struktur Aljabar. Math Didactic : Jurnal Pendidikan Matematika, 3(1), 75-83.

Sanjaya, Wina.2006. Strategi Pembelajaran Berorientasi Standar Proses Pendidikan. Jakarta: Prenada Media Group

Smaldino, S.E., Lowther, Deborah L., Russell, J. D. (2014). Instructional Technology \&Mediafor Learning. Jakarta: KencanaPrenadamedia Grup.

Sumarmo, Utari.(2010). Kemandirian belajar: Apa, Mengapa, dan Bagaimana Dikembangkan Pada Peserta Didik. Diakses di http://math.sps.upi.edu/?p=61.

Wahyuningsih, Dian. 2013. Implementasi Blended Learning By The Constructive Approach(BLCA) untuk Meningkatkan Pemahaman Konsep 
p-ISSN: 2087-3476

e-ISSN: 2541-5700
Pepatuzdu: Media Pendidikan dan Sosial Kemasyarakatan

Vol 17, No. 2, November 2021

DOI: 10.35329/fkip.v17i2.2566

danKemandirian Belajar Mahasiswadalam Matakuliah Interaksi Manusia dan Komputer Prodi TeknologiPendidikan FIPUNY.Yogyakarta: Thesis Universitas Negeri Yogyakarta. Tidak diterbitkan

Yendri, Dodon. 2011. Blended Learning: Model Pembelajaran Kombinasi Elearning dalam Pendidikan Jarak Jauh. Universitas Andalas 